\title{
Quantification of the Expression of HIF-1alpha by Real-Time PCR in Rat Hepatocytes Cultures Invaded by Shigella flexneri under Normoxic and Hypoxic Conditions
}

\author{
Camila Bárbara Cantalupo Lima, Sânia Alves dos Santos, Dahir Ramos de Andrade Júnior \\ Laboratory of Bacteriology (LIM 54), Department of Infectious and Parasitic Diseases, Faculty of Medicine, \\ University of Sao Paulo, Sao Paulo, Brazil \\ Email: saniasan@usp.br
}

Received 4 June 2015; accepted 5 July 2015; published 8 July 2015

Copyright (C 2015 by authors and Scientific Research Publishing Inc.

This work is licensed under the Creative Commons Attribution International License (CC BY).

http://creativecommons.org/licenses/by/4.0/

(c) (i) Open Access

\begin{abstract}
Aim: Shigella flexneri (S. flexneri) is a gram-negative enterobacterium responsible for severe intestinal end systemic infection in humans. The bacteria can reach the liver due to degeneration of the colonic epithelium. Hypoxia is present in many human diseases and can induce the expression of the transcription factor HIF-1alpha that may have a cell protective role. The influence of hypoxia and HIF-1alpha on bacterial infection, studied in this work, is unclear. Hypoxia inducible factor1alpha (HIF-1alpha) is a transcription factor that acts as a master regulator of gene expression induced by hypoxia. Methods: We compared the ability of $S$. flexneri to invade rat hepatocytes in primary culture both in normoxic and hypoxic conditions. We evaluated TNF-alpha released by hepatocytes, apoptosis rate and HIF-1alpha expression by confocal microscopy as well as real time PCR technique. Results: We showed that $S$. flexneri invaded less hepatocytes previously submitted to $24 \mathrm{~h}$ hypoxia $\left(6.5 \% \mathrm{O}_{2}\right)$ than those cultivated in normoxia $\left(21 \% \mathrm{O}_{2}\right)$. $S$. flexneri also induced HIF-1 $\alpha$ expression in hepatocytes, TNF- $\alpha$ secretion and apoptosis. Conclusion: a) Hypoxia alone was not a stimulus to TNF- $\alpha$ secretion, but induced cell apoptosis and HIF-1 $\alpha$ expression; b) S. flexneri was able to invade rat hepatocytes and hypoxia apparently influenced significantly bacterial cell invasiveness; c) HIF-1 $\alpha$ was expressed in hypoxic conditions, and it was also stimulated by $S$. flexneri.
\end{abstract}

\section{Keywords}

Shigella flexneri, Hepatocytes, Cell Hypoxia, Hypoxia-Inducible Factor $1 \alpha$, TNF-Alpha, Apoptosis 


\section{Introduction}

Shigella flexneri (S. flexneri) is a gram-negative enterobacterium responsible for bacillary dysentery in humans. After oral ingestion of about one hundred shigellae, these bacteria reach the colon and may invade the intestinal wall by translocating through M-cells of Peyer's patches [1]. Most of the research of S. flexneri invasiveness in vitro was made in intestinal epithelial cells lineages like CaCo-2 or T84 [2] [3]. However, it is described that bacterial translocation from the gut occurs in disease situations, allowing bacterial access to liver through portal vein [4] [5]. Several study models have been used for S. flexneri research, as intragastric infection in guinea pigs or i.v. rabbit infection. These studies contributed to knowledge of Shigella sp. dissemination mechanisms as well as the influence of this infection to the liver [6] [7]. Factors such as intestinal hypoxia and reperfusion increase bacterial translocation and reduce its hepatic clearance [8]. Hepatitis after Shigella infection has also been reported in humans [9].

Hypoxia is a common condition present in tumors, wounds, atherosclerotic lesions, inflamed or infected tissues [10]. The diseased tissues show several features that can result in a hypoxic microenvironment, such as increased metabolic demand for leukocytes into the inflammatory tissue, microcirculation impairment and microorganisms proliferation [11] [12]. Furthermore, hypoxia is also present in many liver diseases such as tumors, chronic hepatitis and cirrhosis, leading to morphological and functional alterations of the hepatocytes [13]-[15].

Hypoxia inducible factor-1alpha (HIF-1 $\alpha$ ) is a transcription factor that acts as a master regulator of gene expression induced by hypoxia. This factor is considered to be the main regulator of eukaryotic cells responses to physiological and hypoxic stress [16]. Recent studies showed that HIF-1 $\alpha$ was expressed not only in hypoxic cells, but also in infection conditions [17] [18]. HIF-1 $\alpha$ has been described to be expressed in hepatocytes under hypoxia or lipopolysaccharide (LPS) stimuli [19] [20]. However, its expression in bacterial infections of hepatocytes is unclear.

Many cytokines are released by hepatocytes due to hypoxic stress as well as a pathogen invasion. The tumor necrosis factor alpha (TNF- $\alpha$ ) plays an important role in mediating apoptosis and regulating inflammatory responses [21]. Hepatocytes have been known to produce and release TNF- $\alpha$ when exposed to various types of microorganisms as C. albicans, L. monocytogenes, S. typhimurium and hepatitis B virus [22]-[24]. TNF- $\alpha$ released by hepatocytes can be correlated with stress responses caused by $S$. flexneri infection that result in cell death by apoptosis [25]. Circulating TNF- $\alpha$ can increase the fatality in parasitic, bacterial and viral infections [23]. The influence of the hypoxic microenvironment in the TNF- $\alpha$ release by cells is also unclear. The major role of this cytokine appears to be as mediator in the host resistance against invading pathogens [26]. The hypoxic microenvironment may also influence in this process.

In this work we studied the functional and morphological alterations in cultured rat hepatocytes invaded by $S$. flexneri. We also investigated the influence of hypoxia in cellular infection, as well as TNF- $\alpha$ production, HIF$1 \alpha$ expression and apoptosis rates. Our results showed that $S$. flexneri invasion induced TNF- $\alpha$ release and apoptosis in cultured hepatocytes, as well as HIF- $1 \alpha$ expression in these cells. The HIF- $1 \alpha$ expression increased in hypoxic and infected hepatocytes. Hypoxia microenvironment caused alterations in some parameters: decreased TNF- $\alpha$ release and increased rates of apoptosis. Hypoxia also led to a decrease in S. flexneri infection rate.

\section{Material and Methods}

\subsection{Primary Culture of Rat Hepatocytes}

Newborn female Wistar rats were obtained from the Central Bioterium of the Faculty of Medicine, University of São Paulo (USP) weigh 6 - 8 g, in a number of 15 rats per assay. We used female rats only to decrease the cell receptors variation. The primary culture procedure was described elsewhere [23]. Briefly, the hepatocytes were obtained from 15 - 20 Wistar rats livers per assay. The material was then transferred to culture flasks (Nunc, Roskilde, Denmark) covered with laminin ( $50 \mu \mathrm{g} / \mathrm{mL}$; Sigma, St. Louis, MO, USA) and cultured in Williams' E medium enriched with hormones and antibiotics. The cells were cultured at $37^{\circ} \mathrm{C}$ in a humidified atmosphere of $5 \% \mathrm{CO}_{2}$ in air. The study design was approved by the Research Ethics Committee of our institution.

\subsection{Hypoxic Conditions}

Hepatocytes cultured for 8 days were placed into a gas-tight modular chamber (Billups-Rothenberg, Del Mar, 
CA) for $24 \mathrm{~h}$. The chamber was gassed for $30 \mathrm{~min}$ at a flow rate of $10 \mathrm{~L} / \mathrm{min}$ using certified gases containing $100 \% \mathrm{~N}_{2}$ (White Martins, São Paulo, Brazil) and placed in an incubator at $37^{\circ} \mathrm{C}$. The $\mathrm{O}_{2}$ concentration in the culture medium was measured after $24 \mathrm{~h}$ incubation in a radiometer apparatus (Radiometer ABL800 Flex, Denmark), reaching $6.5 \% \mathrm{O}_{2}(43.2 \mathrm{mmHg})$. Culture medium $\mathrm{pH}$ was maintained at 7.4 and had no significant changes during the assays. The experimental groups submitted to $6.5 \% \mathrm{O}_{2}$ for $24 \mathrm{~h}$ are referred as hypoxia $(\mathrm{H})$, while groups cultured in $21 \% \mathrm{O}_{2}(140.5 \mathrm{mmHg})$ are referred as normoxia $(\mathrm{N})$. Another two experimental groups were formed: normoxia + infection with S. flexneri $(\mathrm{N}+\mathrm{I})$ (hepatocytes cultured for 8 days plus $24 \mathrm{~h}$ in normoxia and then infected), and hypoxia + infection with S. flexneri $(\mathrm{H}+\mathrm{I})$ (hepatocytes cultured for 8 days plus $24 \mathrm{~h}$ in hypoxia and then infected).

\subsection{Bacterial Invasion Assay}

Shigella flexneri 2a strain (NCTC 9729) (Adolf Lutz collection, São Paulo, Brazil) was grown in Brain Heart Infusion medium (Difco) for $16 \mathrm{~h}$ at $37^{\circ} \mathrm{C}$. Hepatocytes cultured in 24-well plates (Corning) and coverslips at 1 $\times 10^{5}$ cells $/ \mathrm{mL}$ were infected with $\mathrm{S}$. flexneri at multiplicity of infection (MOI) 500 for $1 \mathrm{~h}$ at $37^{\circ} \mathrm{C}$ with previous centrifugation of cells/bacteria at $1000 \mathrm{rpm}$ for $10 \mathrm{~min}$. In pilot experiments minor concentrations (<MOI 500) showed no cell morphological alterations and major concentrations (>MOI 500) caused total cellular destruction. Hepatocytes were incubated with $50 \mu \mathrm{g} / \mathrm{mL}$ gentamicin (Sigma) for $1 \mathrm{~h}$ at $37^{\circ} \mathrm{C}$ followed by PBS washing, and later lyses with Triton X-100 (Sigma) 1\% during 5 min for intracellular bacteria recovery. The number of viable intracellular bacteria was determined by plating serial dilutions of the cells lysates of 24-well plates on blood agar and later CFU (colony-forming unity) counting.

\subsection{Hematoxylin-Eosin Staining}

Hepatocytes monolayers grown on glass coverslips and were stained by hematoxylin-eosin as described elsewhere [27]. Images were analyzed in an optical microscope with digital image capture system (Leica).

\subsection{TNF- $\alpha$ Detection}

The quantification of TNF- $\alpha$ produced by hepatocyte was performed using ELISA for rat TNF in culture supernatants (Biotrak ELISA; GE Healthcare, Piscataway, NJ, USA) in accordance with the manufacturer's instructions.

\subsection{Apoptosis Detection}

Detection of fragmented DNA (TUNEL technique) was assayed using Fragment End Labeling Kit (FragEL kit; Calbiochem, Oncogene Research Products, Cambridge, MA, USA), in accordance with the manufacturer's instructions. Hepatocytes were cultured in glass coverslips and a total of 10 random fields were counted in fluorescence microscope (Leica).

\subsection{HIF-1 $\alpha$ Detection}

Hepatocytes assayed with bacteria and normoxic/hypoxic conditions attached to glass coverslips were fixed for 10 min with $4 \%$ paraformaldehyde and washed three times in PBS. The cells were permeabilized with $1 \%$ Triton X-100 and then washed two times in PBS. Nonspecific binding sites were blocked with 3\% BSA (Inlab, Brazil) for $30 \mathrm{~min}$. The cells were then incubated with rabbit anti-HIF-1 $\alpha$ antibody diluted 1:50 (Santa Cruz Biotechnology) overnight at $4{ }^{\circ} \mathrm{C}$ in a wet room. After this period cells were washed four times in PBS plus $0.1 \%$ Triton X-100 and then incubated with FITC-conjugated goat anti-rabbit secondary antibody diluted 1:80 (Sigma) for $1 \mathrm{~h}$ at room temperature in a wet room. Cells were then washed four times in PBS $+0.1 \%$ Triton X-100 and mounted with DAPI-containing DABCO media (Sigma). Hepatocytes were visualized under a confocal microscope (Carl Zeiss Laser Scanning Systems_LSM-510) and processed with software Zeiss LSM Image Browser.

The hepatocytes RNA extraction, amplification and Real-time PCR were performed using TaqMan Gene Expression Cells-to-CT Kit (Life Technologies) as described by the manufacturer. $\beta$-Actin (Applied Biossystems) was used as an internal control gene. The results were normalized to $\Delta \Delta \mathrm{Ct}$ values. 


\subsection{Statistical Analysis}

All the experiments were repeated at least ten times and Kruskal-Wallis test with Student's Newman Keuls post-test were used for statistical analysis. The alpha risk was considered statistically significant when $P \leq 0.05$.

\section{Results}

\subsection{Recovery of Intracellular S. flexneri}

Hepatocytes cultured in normoxia showed more intracellular bacteria, reaching values higher than 1000 intracellular bacteria $/ \mathrm{cm}^{2}$ of hepatocytes cultured (Figure 1). Previous hypoxia (24 h) decreased the number of intracellular bacteria for 638.8 in a significative way (Figure 1).

\subsection{TNF- $\alpha$ Secretion and Apoptosis Rate}

There were no significative difference in TNF- $\alpha$ released between normoxic and hypoxic hepatocytes. Hepatocytes released more TNF- $\alpha$ when infected with S. flexneri both in normoxia and hypoxia conditions (Figure 2). All infected groups showed more TNF- $\alpha$ production than control groups (Figure 2).

Hypoxic hepatocytes groups had higher apoptosis rates when compared to normoxic control groups. Hepatocytes infected with $S$. flexneri had similar apoptosis rates when submitted to hypoxia or not. There was a significative difference in apoptosis rate among all groups and normoxic control group (Figure 3).

\subsection{HIF-1 $\alpha$ Expression}

Hepatocytes cultured in normoxic conditions had no HIF- $1 \alpha$ expression as seen with absence of green fluorescence (Figure 4(A)). All others groups expressed HIF-1 $\alpha$ (Figures 4(B)-(D)). Both hypoxia and infection by $S$. flexneri lead to HIF-1 $\alpha$ expression in hepatocytes (Figure 4(C) and Figure 4(B)). We noted that HIF-1 $\alpha$ was distributed both in hepatocytes nuclei and cytoplasm, as seen with DAPI overlap (Figure 4(B1)-4(D1)).

The Real-time PCR quantified HIF- $1 \alpha$ expressed in the same experimental conditions as above. The $\Delta \Delta \mathrm{Ct}$ data obtained were submitted to Newman-Keuls test and plotted in a graph (Figure 5). All comparisons were considered significative $(P \leq 0.0001)$.

\subsection{Morphological Alterations in Rat Hepatocytes after $S$. flexneri Infection}

Hepatocyte viability reached $91.2 \%$ at 8 day of culture, with an average of $1.8 \times 10^{6}$ hepatocytes $/ \mathrm{ml}$ of culture medium. The elements that proved the hepatocytes selectivity in this cell culture model were published previously

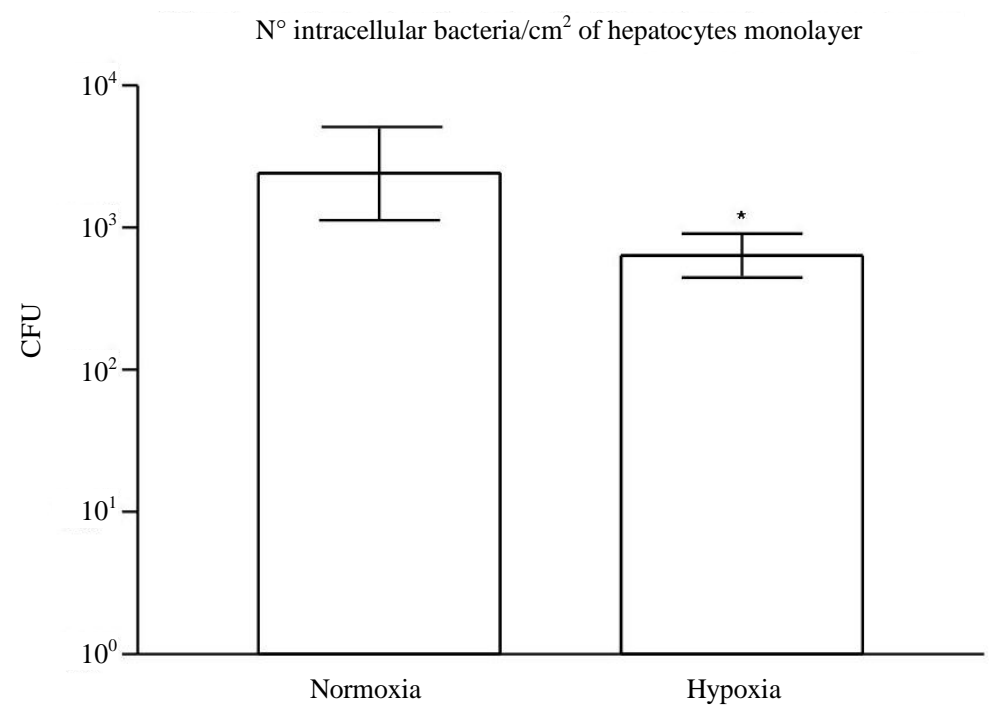

Figure 1. Invasiveness of S. flexneri (MOI 500) after $1 \mathrm{~h}$ infection of rat hepatocytes cultured under normoxic or hypoxic conditions $\left({ }^{*} P<0.001\right)$. 


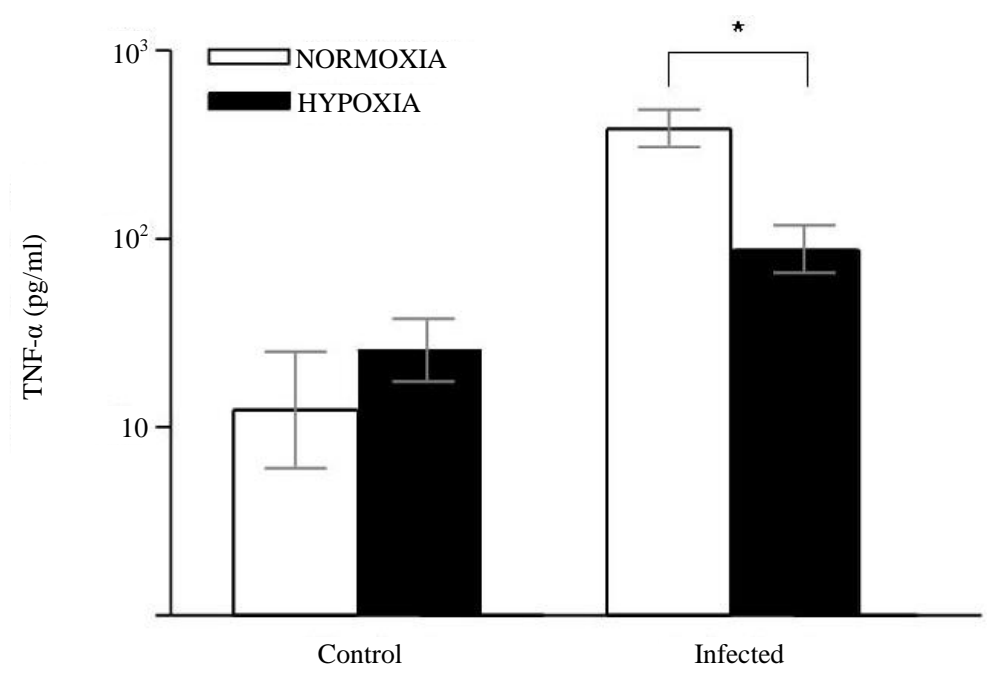

Figure 2. TNF- $\alpha$ released in culture supernatants of rat hepatocytes under normoxia or hypoxia $\left(6.5 \% \mathrm{O}_{2}\right)$ for $24 \mathrm{~h}$, and infected with $S$. flexneri $\left({ }^{*} \mathrm{P}<\right.$ 0.001).

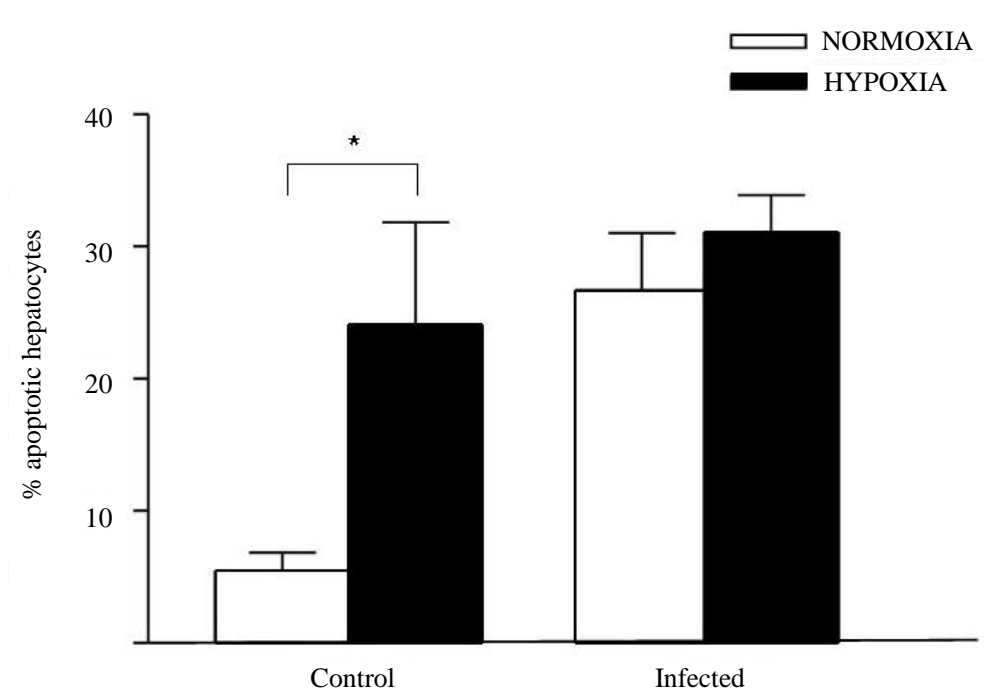

Figure 3. Percentage of apoptotic hepatocytes cultured under normoxic or hypoxic conditions $\left(6.5 \% \mathrm{O}_{2}\right)$ and infected with $S$. flexneri $\left({ }^{*} P<0.001\right)$.

[23]. Cell viability of all experimental groups (normoxia, hypoxia, normoxia + infection and hypoxia + infection) ranged from 74 to 87 percent, showing no significant difference (data not shown). In optical microscopy normoxic hepatocyte cultures were seen arranged in monolayer with wide cell junctions (Figure 6(A)), while cells submitted to $24 \mathrm{~h}$ hypoxia showed picnotic nuclei, as well as monolayer ruptures (Figure 6(C)). Hepatocytes infected with $S$. flexneri had severe monolayer disruption and cytoplasmic shrinkage (Figure 6(B)), while cells exposed to 24 h hypoxia and infected later showed also cytoplasmic vacuoles (Figure 6(D)).

\section{Discussion}

The minimum time required for hepatocyte's bacterial invasion was one hour. This time was lower when compared to infected intestinal tumoral lineages with the same rate of bacterial recovery [28]. Interestingly, S. flexneri invaded less hepatocytes under hypoxia, in agreement with other studies using different pathogens and cells [29]-[31]. Hypoxia can modify gene expression, intra and extracellular $\mathrm{pH}$ as well as membrane receptors [32]-[34]. We can speculate that these factors contributed to the lower entrance of bacteria into hepatocytes. 


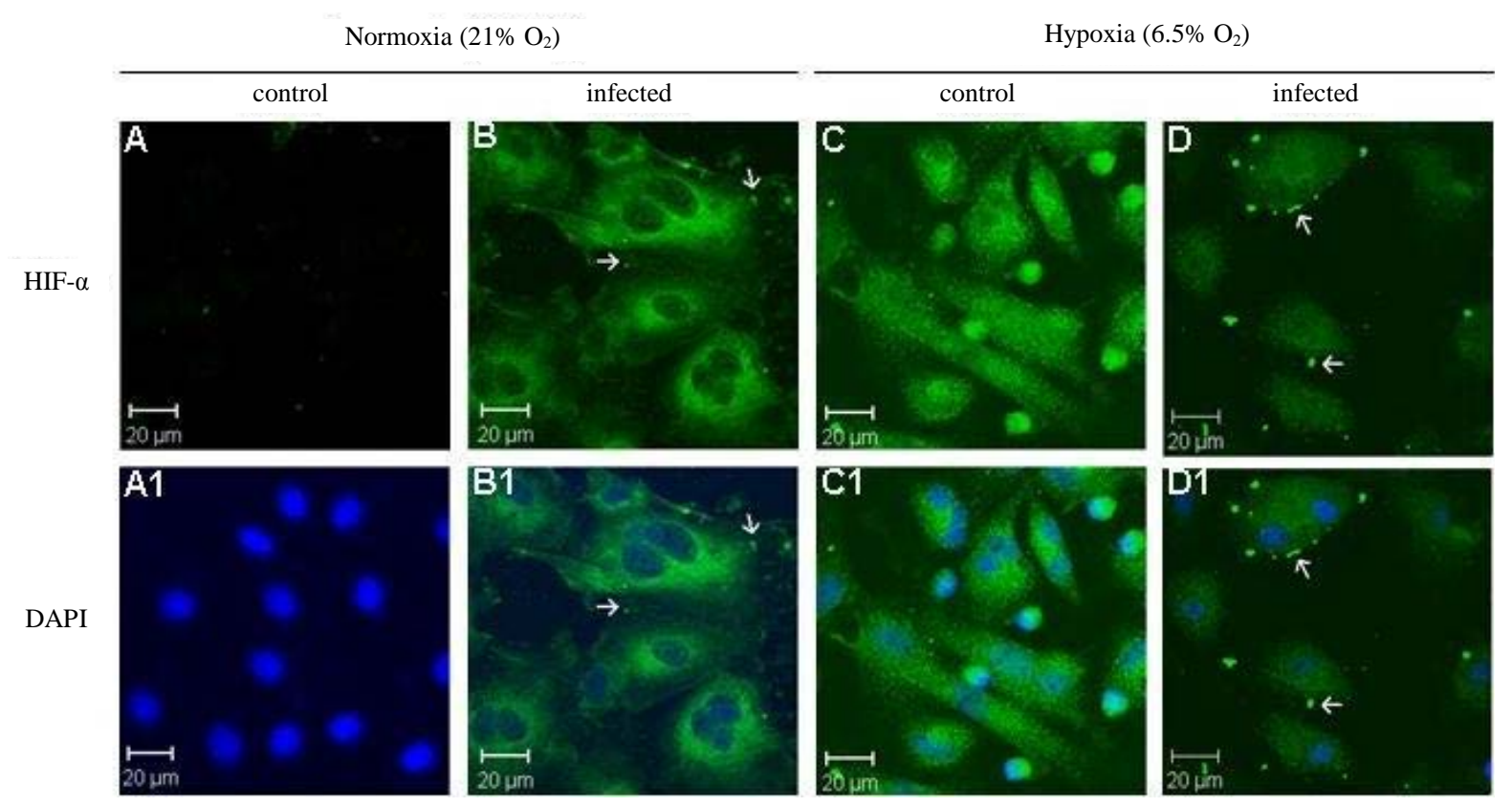

Figure 4. HIF-1 $\alpha$ expression in rat hepatocytes in following conditions: A: normoxia control, B: normoxia infected, C: hypoxia control, D: hypoxia infected; A1: normoxia stained with DAPI, B1: normoxia infected stained with DAPI/HIF antibody, C1: hypoxia stained with DAPI, D1: hypoxia stained with DAPI/HIF antibody. Arrows indicate the bacteria in the field $(\times 400)$.

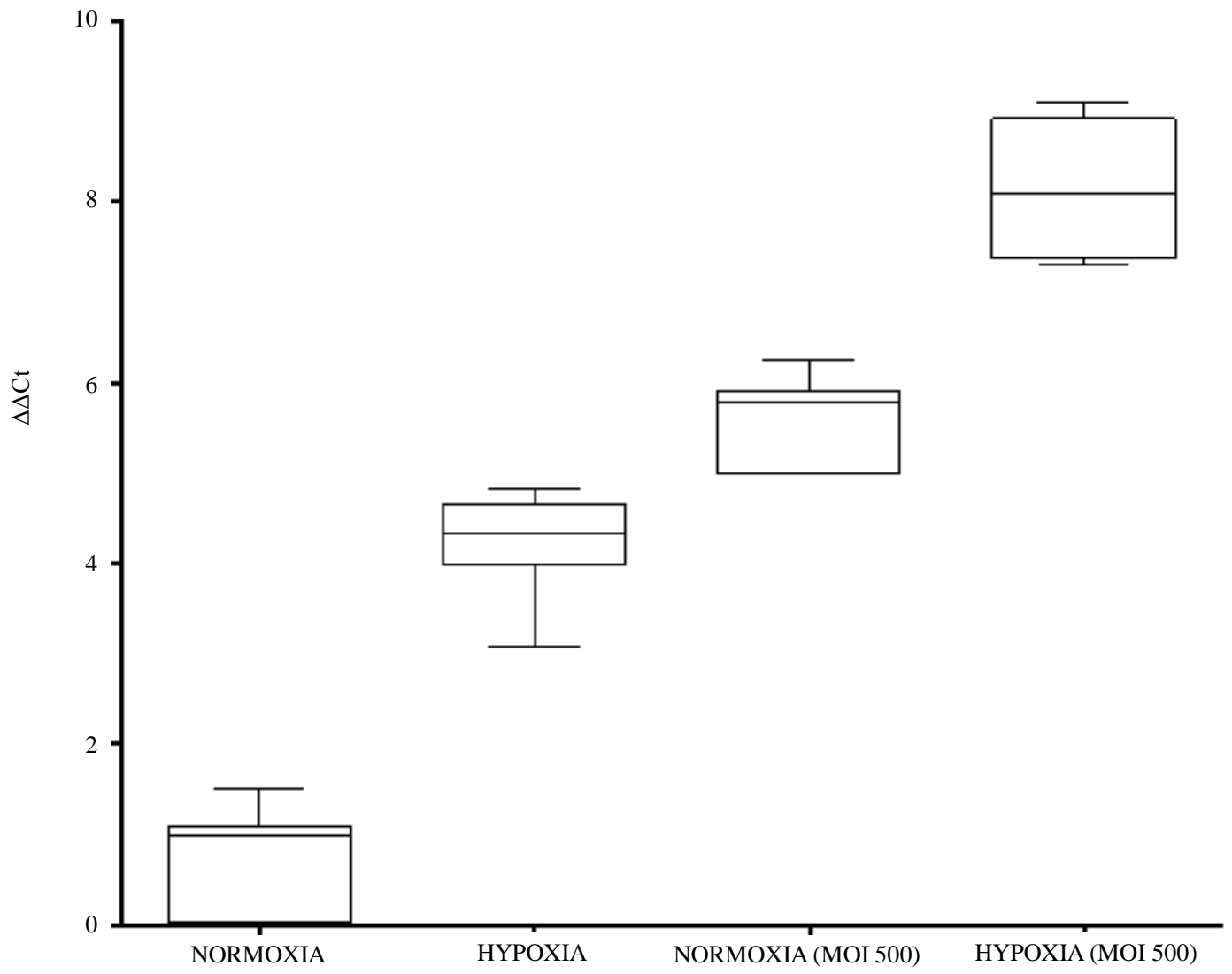

Figure 5. HIF-1alpha expressed quantified in hepatocytes cultured under normoxic or hypoxic conditions $\left(6.5 \% \mathrm{O}_{2}\right)$ with and without infection by S. flexneri MOI 500 (Real-time PCR technique) $(P<0.0001)$. 
Normoxia $\left(21 \% \mathrm{O}_{2}\right)$

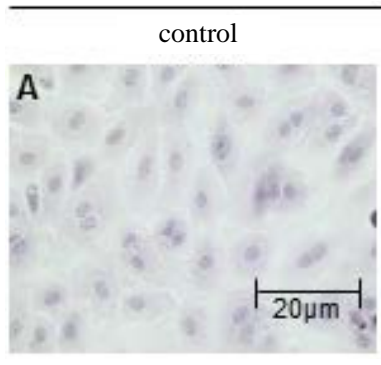

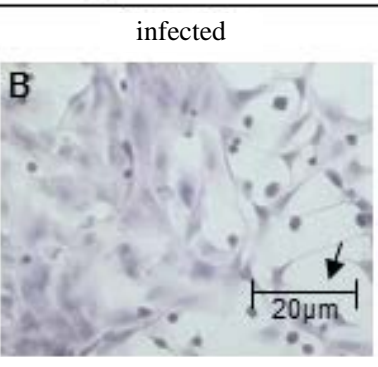

Hypoxia $\left(6.5 \% \mathrm{O}_{2}\right)$

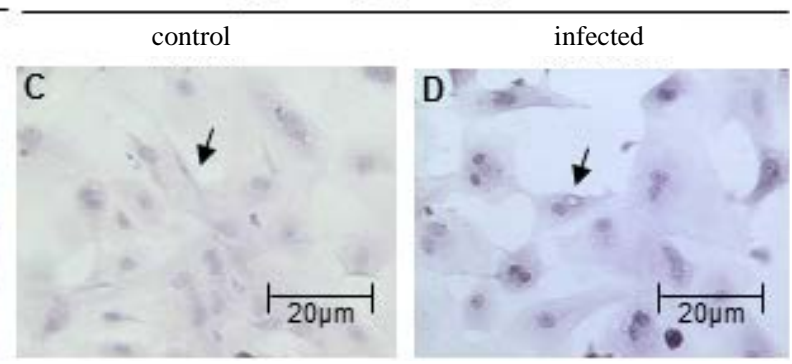

Figure 6. Rat hepatocytes infected with S. flexneri at MOI 500 in normoxic or hypoxic conditions by HE staining. Arrows indicate cell monolayer rupture (B), picnotic nuclei (C) and intracellular vacuoles (D) $(\times 400)$.

Marteyn et al. [35] showed that bacteria cultured under hypoxic conditions increase their ability to invade intestinal cells. However, in our study, S. flexneri was grown under aerobic conditions $\left(21 \% \mathrm{O}_{2}\right)$ and then placed in contact with hepatocytes in hypoxic microenvironment. Furthermore, the same group demonstrated that the epithelial surface in gastrointestinal tract has a larger oxygen supply than intestinal lumen and that $S$. flexneri had the ability to detect varying oxygen tensions, which allowed type III secretion system (T3SS) activation at its precise site of action, enhancing bacterial invasion and virulence mainly in irrigated tissues. We hypothesized that bacterial entry in hypoxic hepatocytes was reduced by the difficulty of $S$. flexneri to recognize their receptors. The molecular mechanisms involved in this phenomenon are unclear and await further studies.

We obtained no significant differences of TNF- $\alpha$ released by hepatocytes under normoxia and hypoxia. Several studies had demonstrated a synergic relation between hypoxia and LPS to enhance the production and release of TNF- $\alpha$ from macrophages [36]. This phenomenon is attributed mainly to transcriptional upregulation of nuclear factor NF- $\kappa \mathrm{B}$ [37]. However, hypoxia has also been showed to inhibit or not change the amounts of secreted TNF- $\alpha$ [38], in a similar way to our results obtained in hypoxic hepatocytes. The cause of reduction in TNF- $\alpha$ secretion could be explained by an enhanced sensitivity of hepatocytes to hypoxia-mediated apoptosis. Furthermore, the effects of circulating or secreted TNF- $\alpha$ may also be regulated by its binding to the soluble forms of TNF receptors, sTNFR-I and sTNFR-II, which can inhibit its activity [39] [40]. Indeed, elevated levels of these receptors have been found in patients with different diseases, whose common denominator is hypoxia [36]. Even though, the same levels of TNF- $\alpha$ secretion in both hypoxic and normoxic cells could also be due to TNF- $\alpha$ lysosomal degradation in cytoplasm before their liberation, as described by Lahat et al. [36].

Our results about TNF- $\alpha$ secretion in hypoxia microenvironment suggest that infections in these conditions could be more difficult to be eliminated by immune system, since TNF- $\alpha$ is a primordial cytokine responsible for inflammatory responses.

Hepatocytes submitted to hypoxia had increased apoptosis rates compared to normoxic cells. This phenomenon has been observed in other studies [41] [42]. As apoptosis can be stimulated by different pathways, we hypothesized that in this case it is not being activated by TNF- $\alpha$, due to the unchanged state of the cytokine in hypoxic conditions.

S. flexneri infection increased the apoptosis rates significantly only in normoxic hepatocytes when compared to normoxic control. Hepatocytes infected with other bacteria had similar apoptosis rates [43]. However, hypoxia did not have a synergistic effect with $S$. flexneri, because there was no significant difference between infection groups. Apoptosis induced by $S$. flexneri can stimulate cell release of pro-inflammatory cytokines, such as IL-1b and IL-18 [44].

HIF- $1 \alpha$ is known to be expressed in cells exposed to hypoxia, and it acts a master regulator of gene transcription in this condition. In our study, hypoxia induced HIF-1 $\alpha$ expression both in nucleus and cytoplasm of hepatocytes, while normoxic cells had no HIF- $1 \alpha$ expression. Hepatocytes infected with S. flexneri also had HIF-1 $\alpha$ expression both in hypoxic and normoxic conditions. These results showed that $S$. flexneri was able to induce hepatocytes HIF- $1 \alpha$ expression in according to the results found by other groups using different infectious agents [45] [46]. The quantification of HIF-1 $\alpha$ made by Real-time PCR confirmed the qualitative results, comparing the expression of HIF- $1 \alpha$ versus $\beta$-actin expression. S. flexneri infection significantly increased the HIF-1 $\alpha$ expression both in normoxia and in hypoxia microenvironment. We speculate that hypoxia and $S$. flexneri infection act synergistically to increase this transcription factor in the cells. 
Regueira et al. [47] showed that TNF- $\alpha$ induced increases in HIF-1 $\alpha$ protein levels in a time-dependent form in hepatocytes under normoxic conditions. In our study the infection groups presented HIF-1 $\alpha$ expression and TNF- $\alpha$ release. Only hypoxic group presented HIF- $1 \alpha$ expression and unchanged TNF- $\alpha$ release. Future studies are needed to determine whether TNF- $\alpha$ also influences HIF-1 $\alpha$ expression under hypoxia.

\section{Conclusion}

Overall, our results contribute to a better knowledge of the interaction between hepatocytes and invasive bacteria $S$. flexneri. Hypoxia appears to influence significantly in bacterial cell invasiveness, as well as the release of TNF- $\alpha$ apoptosis rates and HIF-1 $\alpha$ expression. Future studies about the influence of these factors on the Shigel$l a$ 's virulence will be important to help combat this aggressive pathogen.

\section{Acknowledgements}

This work was supported by the Fundação de Amparo à Pesquisa do Estado de São Paulo (FAPESP). We also thank the Núcleo de Microscopia Confocal do Hospital das Clínicas da Faculdade de Medicina da Universidade de São Paulo.

\section{References}

[1] Sansonetti, P.J. (2001) Microbes and Microbial Toxins: Paradigms for Microbial-Mucosal Interactions. III. Shigellosis: from Symptoms to Molecular Pathogenesis. American Journal of Physiology-Gastrointestinal and Liver Physiology, 280, 319-323.

[2] Zurawski, D.V., Mumy, K.L., Faherty, C.S., McCormick, B.A. and Maurelli, A.T. (2009) Shigella flexneri Type III Secretion System Effectors OspB and OspF Target the Nucleus to Downregulate the Host Inflammatory Response via Interactions with Retinoblastoma Protein. Molecular Microbiology, 71, 350-368. http://dx.doi.org/10.1111/j.1365-2958.2008.06524.x

[3] Flamant, M., Aubert, P., Rolli-Derkinderen, M., Bourreille, A., Neunlist, M.R., Mahé, M.M., Meurette, G., Marteyn, B., Savidge, T., Galmiche, J.P., Sansonetti, P.J. and Neunlist, M. (2011) Enteric Glia Protect against Shigella flexneri Invasion in Intestinal Epithelial Cells: A Role for S-Nitrosoglutathione. Gut, 60, 473-484. http://dx.doi.org/10.1136/gut.2010.229237

[4] Macutkiewicz, C., Carlson, G., Clark, E., Dobrindt, U., Roberts, I. and Warhurst, G. (2008) Characterisation of Escherichia coli Strains Involved in Transcytosis across Gut Epithelial Cells Exposed to Metabolic and Inflammatory Stress. Microbes and Infection, 10, 424-431. http://dx.doi.org/10.1016/j.micinf.2008.01.001

[5] Sandler, N.G., Koh, C., Roque, A., Eccleston, J.L., Siegel, R.B., Demino, M., Kleiner, D.E., Deeks, S.G., Liang, T.J., Heller, T. and Douek, D.C. (2011) Host Response to Translocated Microbial Products Predicts Outcomes of Patients with HBV or HCV Infection. Gastroenterology, 141, 1220-1230. http://dx.doi.org/10.1053/j.gastro.2011.06.063

[6] Bernardini, M.L., Arondel, J., Martini, I., Aidara, A. and Sansonetti, P.J. (2001) Parameters Underlying Successful Protection with Live Attenuated Mutants in Experimental Shigellosis. Infection and Immunity, 69, 1072-1083. http://dx.doi.org/10.1128/IAI.69.2.1072-1083.2001

[7] Etheridge, M.E., Hoque, A.T. and Sack, D.A. (1996) Pathologic Study of a Rabbit Model for Shigellosis. Laboratory Animal Science, 46, 61-66.

[8] Abdala, E., Baía, C.E., Mies, S., Massarollo, P.C., de Paula Cavalheiro, N., Baía, V.R., Inácio, C.A., Sef, H.C. and Barone, A.A. (2007) Bacterial Translocation during Liver Transplantation: A Randomized Trial Comparing Conventional with Venovenous Bypass vs. Piggyback Methods. Liver Transplantation, 13, 488-496. http://dx.doi.org/10.1002/lt.21085

[9] Stern, M.S. and Gitnick, G.L. (1976) Shigella Hepatitis. JAMA, 235, 2628. http://dx.doi.org/10.1001/jama.1976.03260500044030

[10] Bosseto, M.C., Palma, P.V., Covas, D.T. and Giorgio, S. (2010) Hypoxia Modulates Phenotype, Inflammatory Response, and Leishmanial Infection of Human Dendritic Cells. APMIS, 118, 108-114. http://dx.doi.org/10.1111/j.1600-0463.2009.02568.x

[11] Lewis, J.S., Lee, J.A., Underwood, J.C., Harris, A.L. and Lewis, C.E. (1999) Macrophage Responses to Hypoxia: Relevance to Disease Mechanisms. Journal of Leukocyte Biology, 66, 889-900.

[12] Murdoch, C., Muthana, M. and Lewis, C.E. (2005) Hypoxia Regulates Macrophage Functions in Inflammation. The Journal of Immunology, 175, 6257-6263. http://dx.doi.org/10.4049/jimmunol.175.10.6257

[13] Bottaro, D.P. and Liotta, L.A. (2003) Cancer: Out of Air Is Not Out of Action. Nature, 423, 593-595. 
http://dx.doi.org/10.1038/423593a

[14] Raurich, J.M., Llompart-Pou, J.A., Ferreruela, M., Colomar, A., Molina, M., Royo, C., Ayestarán, I. and Ibáñez, J. (2011) Hypoxic Hepatitis in Critically Ill Patients: Incidence, Etiology and Risk Factors for Mortality. Journal of Anesthesia, 25, 50-56. http://dx.doi.org/10.1007/s00540-010-1058-3

[15] Rosmorduc, O., Wendum, D., Corpechot, C., Galy, B., Sebbagh, N., Raleigh, J., Housset, C. and Poupon, R. (1999) Hepatocellular Hypoxia-Induced Vascular Endothelial Growth Factor Expression and Angiogenesis in Experimental Biliary Cirrhosis. The American Journal of Pathology, 155, 1065-1073. http://dx.doi.org/10.1016/S0002-9440(10)65209-1

[16] Wang, G.L. and Semenza, G.L. (1995) Purification and Characterization of Hypoxia-Inducible Factor 1. The Journal of Biological Chemistry, 270, 1230-1237. http://dx.doi.org/10.1074/jbc.270.3.1230

[17] Kempf, V.A.J., Lebiedziejewski, M., Alitalo, K., Wälzlein, J.H., Ehehalt, U., Fiebig, J., Huber, S., Schütt, B., Sander, C.A., Müller, S., Grassl, G., Yazdi, A.S., Brehm, B. and Autenrieth, I.B. (2005) Activation of Hypoxia-Inducible Factor-1 in Bacillary Angiomatosis: Evidence for a Role of Hypoxia-Inducible Factor-1 in Bacterial Infections. Circulation, 111, 1054-1062. http://dx.doi.org/10.1161/01.CIR.0000155608.07691.B7

[18] Degrossoli, A., Bosetto, M.C., Lima, C.B. and Giorgio, S. (2007) Expression of Hypoxia-Inducible Factor 1alpha in Mononuclear Phagocytes Infected with Leishmania amazonensis. Immunology Letters, 114, 119-125. http://dx.doi.org/10.1016/j.imlet.2007.09.009

[19] Kietzmann, T., Cornesse, Y., Brechtel, K., Modaressi, S. and Jungermann, K. (2001) Perivenous Expression of the mRNA of the Three Hypoxia-Inducible Factor $\alpha$-Subunits, HIF1 $\alpha$, HIF2 $\alpha$ and HIF3 $\alpha$, in Rat Liver. Biochemical Journal, 354, 531-537. http://dx.doi.org/10.1042/0264-6021:3540531

[20] Kim, H.Y., Kim, Y.H., Nam, B.H., Kong, H.J., Kim, H.H., Kim, Y.J., An, W.G. and Cheong, J. (2007) HIF-1 $\alpha$ Expression in Response to Lipopolysaccaride Mediates Induction of Hepatic Inflammatory Cytokine TNF $\alpha$. Experimental Cell Research, 313, 1866-1876. http://dx.doi.org/10.1016/j.yexcr.2007.03.009

[21] Gao, L.Y. and Kwaik, A. (2000) The Modulation of Host Cell Apoptosis by Intracellular Bacterial Pathogens. Trends in Microbiology, 8, 306-313. http://dx.doi.org/10.1016/S0966-842X(00)01784-4

[22] Renna, M.S., Correa, S.G., Porporatto, C., Figueredo, C.M., Aoki, M.P., Paraje, M.G. and Sotomayor, C.E. (2006) Hepatocellular Apoptosis during Candida albicans Colonization: Involvement of TNF- $\alpha$ and Infiltrating Fas-L Positive Lymphocytes. International Immunology, 18, 1719-1728. http://dx.doi.org/10.1093/intimm/dxl106

[23] dos Santos, S.A., de Andrade Jr., D.R. and de Andrade, D.R. (2011) TNF- $\alpha$ Production and Apoptosis in Hepatocytes after Listeria monocytogenes and Salmonella Typhimurium Invasion. Revista do Instituto de Medicina Tropical de São Paulo, 53, 107-112.

[24] Lara-Pezzi, E., Majano, P.L., Gómez-Gonzalo, M., García-Monzón, C., Moreno-Otero, R., Levrero, M. and López-Cabrera, M. (1998) The Hepatitis B Virus X Protein Up-Regulates Tumor Necrosis Factor $\alpha$ Gene Expression in Hepatocytes. Hepatology, 28, 1013-1021. http://dx.doi.org/10.1002/hep.510280416

[25] Beyaert, R. and Fiers, W. (1994) Molecular Mechanisms of Tumor Necrosis Factor-Induced Cytotoxicity. What We Do Understand and What We Do Not. FEBS Letters, 340, 9-16. http://dx.doi.org/10.1016/0014-5793(94)80163-0

[26] Fiers, W. (1991) Tumor Necrosis Factor. Characterization at the Molecular, Cellular and in Vivo Level. FEBS Letters, 285, 199-212. http://dx.doi.org/10.1016/0014-5793(91)80803-B

[27] dos Santos, S.A., de Andrade, D.R. and de Andrade Jr., D.R. (2005) Rat Hepatocyte Invasion by Listeria monocytogenes and Analysis of TNF- $\alpha$ Role in Apoptosis. Revista do Instituto de Medicina Tropical de São Paulo, 47, 73-80. http://dx.doi.org/10.1590/S0036-46652005000200003

[28] Mounier, J., Vasselon, T., Hellio, R., Lesourd, M. and Sanonetti, P.J. (1992) Shigella flexneri Enters Human Colonic Caco-2 Epithelial Cells through the Basolateral Pole. Infection and Immunity, 60, 237-248.

[29] Roth, A., Königb, P., van Zandbergenc, G., Klingerb, M., Hellwig-Bürgeld, T., Däubenere, W., Bohlmannf, M.K. and Ruppa, J. (2010) Hypoxia Abrogates Antichlamydial Properties of IFN- $\gamma$ in Human Fallopian Tube Cells in Vitro and ex Vivo. PNAS, 107, 19502-19507. http://dx.doi.org/10.1073/pnas.1008178107

[30] Spear, W., Chan, D., Coppens, I., Johnson, R.S., Giaccia, A. and Blader, I.J. (2006) The Host Cell Transcription Factor Hypoxia-Inducible Factor 1 is Required for Toxoplasma gondii Growth and Survival at Physiological Oxygen Levels. Cellular Microbiology, 8, 339-352.

[31] Colhone, M.C., Arrais-Silva, W.W., Picoli, C. and Giorgio, S. (2004) Effect of Hypoxia on Macrophage Infection by Leishmania amazonensis. Journal of Parasitology, 90, 510-515. http://dx.doi.org/10.1645/GE-3286

[32] Wenger, R.H. (2002) Cellular Adaptation to Hypoxia: $\mathrm{O}_{2}$-Sensing Protein Hydroxylases, Hypoxia-Inducible Transcription Factors, and $\mathrm{O}_{2}$-Regulated Gene Expression. The FASEB Journal, 16, 1151-1162.

http://dx.doi.org/10.1096/fj.01-0944rev 
[33] Herman, B., Gores, G.J., Nieminen, A.L., Kawanishi, T., Harman, A. and Lemasters, J.J. (1990) Calcium and pH in Anoxic and Toxic Injury. Critical Reviews in Toxicology, 21, 127-148. http://dx.doi.org/10.3109/10408449009089876

[34] Berger, M.L., Reynolds, R.C., Hagler, H.K., Bellotto, D., Parsons, D., Mulligan, K.J. and Buja, L.M. (1989) Anoxic Hepatocyte Injury: Role of Reversible Changes in Elemental Content and Distribution. Hepatology, 9, 219-228. http://dx.doi.org/10.1002/hep.1840090210

[35] Marteyn, B., West, N.P., Browning, D.F., Cole, J.A., Shaw, J.G., Palm, F., Mounier, J., Prévost, M.C., Sansonetti, P. and Tang, C.M. (2010) Modulation of Shigella Virulence in Response to Available Oxygen in Vivo. Nature, 465, 355-358. http://dx.doi.org/10.1038/nature08970

[36] Lahat, N., Rahat, M.A., Kinarty, A., Weiss-Cerem, L., Pinchevski, S. and Bitterman, H. (2008) Hypoxia Enhances Lysosomal TNF- $\alpha$ Degradation in Mouse Peritoneal Macrophages. American Journal of Physiology-Cell Physiology, 295, C2-C12. http://dx.doi.org/10.1152/ajpcell.00572.2007

[37] Chandel, N.S., Trzyna, W.C., McClintock, D.S. and Schumacker, P.T. (2000) Role of Oxidants in NF-Kappa B Activation and TNF- $\alpha$ Gene Transcription Induced by Hypoxia and Endotoxin. The Journal of Immunology, 165, 1013-1021. http://dx.doi.org/10.4049/jimmunol.165.2.1013

[38] Ndengele, M.M., Bellone, C.J., Lechner, A.J. and Matuschak, G.M. (2000) Brief Hypoxia Differentially Regulates LPS-Induced IL-1 and TNF-alpha Gene Transcription in RAW 264.7 Cells. American Journal of Physiology. Lung Cellular and Molecular Physiology, 278, L1289-L1296.

[39] Ammirati, M., Rao, S. and Granger, G. (2001) Detection of TNF Inhibitors (Soluble Receptors) in the Sera and Tumor Cyst Fluid of Patients with Malignant Astrocytomas of the Brain. Frontiers in Bioscience, 6, B17-B24. http://dx.doi.org/10.2741/Ammirat

[40] Cinat, M.E., Waxman, K., Granger, G.A., Pearce, W., Annas, C. and Daughters, K. (1994) Trauma Causes Sustained Elevation of Soluble Tumor Necrosis Factor Receptors. Journal of the American College of Surgeons, 179, 529-537.

[41] Riva, C., Chauvin, C., Pison, C. and Leverve, X. (1998) Cellular Physiology and Molecular Events in Hypoxia-Induced Apoptosis. Anticancer Research, 18, 4729-4736.

[42] Crenesse, D., Gugenheim, J., Hornoy, J., Tornieri, K., Laurens, M., Cambien, B., Lenegrate, G., Cursio, R., De Souza, G., Auberger, P., Heurteaux, C., Rossi, B. and Schmid-Alliana, A. (2000) Protein Kinase Activation by Warm and

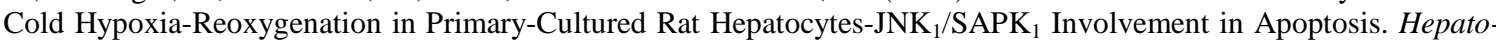
logy, 32, 1029-1036. http://dx.doi.org/10.1053/jhep.2000.19065

[43] Delpino, M.V., Barrionuevo, P., Scian, R., Fossati, C.A. and Baldi, P.C. (2010) Brucella-Infected Hepatocytes Mediate Potentially Tissue-Damaging Immune Responses. Journal of Hepatology, 53, 145-154. http://dx.doi.org/10.1016/j.jhep.2010.02.028

[44] Navarre, W.W. and Zychlinsky, A. (2000) Pathogen-Induced Apoptosis of Macrophages: A Common End for Different Pathogenic Strategies. Cellular Microbiology, 2, 265-273. http://dx.doi.org/10.1046/j.1462-5822.2000.00056.X

[45] Bhattacharyya, A., Chattopadhyay, R., Hall, E.H., Mebrahtu, S.T., Ernst, P.B. and Crowe, S.E. (2010) Mechanism of Hypoxia-Inducible Factor $1 \alpha$-Mediated Mcl1 Regulation in Helicobacter pylori-Infected Human Gastric Epithelium. American Journal of Physiology_-Gastrointestinal and Liver Physiology, 299, G1177-G1186. http://dx.doi.org/10.1152/ajpgi.00372.2010

[46] Nakamura, M., Bodily, J.M., Beglin, M., Kyo, S., Inoue, M. and Laimins, L.A. (2009) Hypoxia-Specific Stabilization of HIF-1alpha by Human Papillomaviruses. Virology, 387, 442-448. http://dx.doi.org/10.1016/j.virol.2009.02.036

[47] Regueira, T., Lepper, P.M., Brandt, S., Ochs, M., Vuda, M., Takala, J., Jakob, S.M. and Djafarzadeh, S. (2009) Hypoxia Inducible Factor- $1 \alpha$ Induction by Tumor Necrosis Factor- $\alpha$, but Not by Toll-Like Receptor Agonists, Modulates Cellular Respiration in Cultured Human Hepatocytes. Liver International, 29, 1582-1592. http://dx.doi.org/10.1111/j.1478-3231.2009.02109.x 